\title{
Liter per Micromole per Day
}

National Cancer Institute

\section{Source}

National Cancer Institute. Liter per Micromole per Day. NCI Thesaurus. Code C85668.

Liters per micromole per day. 